\title{
Electron Microscopic Localization of Immunoreactive Enkephalinase (EC 3.4.24.11) in the Neostriatum of the Rat
}

\author{
D. Marcel, ${ }^{1}$ H. Pollard, ${ }^{2}$ P. Verroust, ${ }^{3}$ J. C. Schwartz, ${ }^{2}$ and A. Beaudet ${ }^{1}$ \\ 'Montreal Neurological Institute, Montreal, Quebec, Canada H3A 2B4, 2Unité de Neurobiologie et Pharmacologie de \\ I'INSERM, Centre Paul Broca, 75014 Paris, France, and 'Unité de Néphrologie Normale et Pathologique de I'INSERM, \\ Hôpital Tenon, 75970 Paris, Cedex 20, France
}

The fine structural distribution of the enzyme-neutral endopeptidase EC 3.4.24.11 (enkephalinase) was examined by immunoradioautography (using an iodinated monoclonal antibody) and peroxidase immunocytochemistry (using the same probe in nonradioactive form) in the neostriatum of the rat. At the light microscopic level, both techniques revealed a heterogeneous distribution of immunoreactive enkephalinase in the caudoputamen, characterized by the presence of patches of intense immunolabeling prominent against a relatively strong immunoreactive matrix, a pattern reminiscent of mu opioid receptors radioautographically labeled in the same region. Pilot experiments indicated that fixation of the brain with a mixture of $4 \%$ paraformaldehyde, $0.05 \%$ glutaraldehyde, and $0.2 \%$ picric acid did not modify the distribution and only slightly reduced the intensity of striatal enkephalinase antigenicity, provided that the postfixation period did not exceed $1 \mathrm{hr}$. In the neostriatum of animals fixed according to this protocol, enkephalinase immunoreactivity was found by electron microscopic immunoradioautography to be exclusively confined to neuronal and glial membrane interfaces. Immunoperoxidase cytochemistry confirmed the association of immunoreactive enkephalinase with the plasma membrane of neurons and, to a lesser extent, of astrocytes and oligodendrocytes. Both immunoradioautographic and immunoperoxidase techniques revealed a predominant association of the enzyme with neuronal perikarya and dendrites. The morphological features of the labeled perikarya, together with the presence of immunoreactive dendritic spines, suggested that some of these neurons corresponded to striatofugal medium spiny neurons. Immunoreactive enkephalinase was also detected at the level of myelinated and unmyelinated axons and axon terminals. These axons could potentially have originated from intrinsic striatal neurons or from the substantia nigra. Statistical analysis of silver grain distribution in electron microscopic immunoradioautographs indicated that immunoreactive enkephalinase was not preferentially concentrated at the level of specific membrane interfaces, but rather, was

\footnotetext{
Received Jan. 30, 1990; revised Apr. 9, 1990; accepted Apr. 12, 1990.

This work was supported by the Medical Research Council of Canada and by a France-Quebec travel exchange program. We thank Kathleen Leonard for expert technical assistance, Charles Hodge for photographic work, and Beverley Lindsay for typing the manuscript.

Correspondence should be addressed to Alain Beaudet, M.D., Ph.D., Neuroanatomy Laboratory, Room 821, Montreal Neurological Institute, 3801 University Street, Montreal, Quebec, Canada H3A 2 B4.

Copyright (C) 1990 Society for Neuroscience $0270-6474 / 90 / 082804-14 \$ 03.00 / 0$
}

more or less uniformly distributed on the surface of neurons and/or glial cells. A similarly diffuse localization of the enzyme was apparent in peroxidase-reacted material, though the latter technique also revealed a microheterogeneity in the deposition of the reaction product along the labeled membranes. Finally, quantitative analysis of immunoradioautographs clearly indicated an absence of enkephalinase enrichment at the level of synaptic junctions. The similarity between the light and electron microscopic distribution of enkephalinase observed in the present study, and that previously reported for mu opioid receptors, lends support to the concept that this ectoenzyme may be involved in the inactivation of endogenous opioids in the mammalian neostriatum.

The discovery of endogenous opioid peptides in the mammalian CNS rapidly led to a search for enzymes implicated in the inactivation of their presumptive neurotransmitter action (for a review, see Schwartz et al., 1981; Hersh, 1982; McKelvy, 1983). One such enzyme was characterized in rat brain homogenates by Malfroy et al. (1978) and was given the name "enkephalinase" on the basis of its localization and ability to cleave the Gly-3, Phe- 4 amide bond of enkephalins. Further studies confirmed the implication of enkephalinase, later referred to as membrane metalloendopeptidase and numbered EC 3.4 .24 .11 by the enzyme commission (1988), in the biological inactivation of opioid peptides in vivo (for reviews, see Schwartz, 1983, 1988; Schwartz et al., 1985; Lynch and Snyder, 1986; McKelvy and Blumberg, 1986). However, other experiments indicated that this enzyme did not display narrow substrate specificity for opioid peptides but could cleave other neuropeptides such as bradykinin (Swerts et al., 1979; Gafford et al., 1983; Stephenson and Kenny, 1987a), angiotensin II (Swerts et al., 1979; Gafford et al., 1983; Stephenson and Kenny, 1987a), substance P and other tachykinins (Matsas et al., 1984, 1986; Stephenson and Kenny, 1987a), neurotensin (Checler et al., 1983), atrial natriuretic peptide (Stephenson and Kenny, 1987b; Sonnenberg et al., 1988; Gros et al., 1989), and cholecystokinin (Zuzel et al., 1985) in vitro. Furthermore, recent evidence suggests that such catalytic activity might be implicated in the in vivo biological inactivation of at least some of these peptides (Dubuc et al., 1989; Gros et al., 1989). It follows that the anatomical localization of enkephalinase relative to the sites of release and/or action of these different neuropeptides may play a critical role in determining the physiological implication of the enzymes in their inactivation.

Early studies based on the measurement of enkephalinase activity in mouse (Malfroy et al., 1978, 1979), pig (Relton et 
al., 1983), and human (Llorens-Cortes et al., 1982) brain homogenates demonstrated a highly heterogeneous distribution of this enzyme in the mammalian CNS. Further work, based on the autoradiographic localization of selectively bound ${ }^{3} \mathrm{H}-\mathrm{la}$ beled enkephalinase inhibitors (Waksman et al., 1984, 1986a, b; Pollard et al., 1987a) or on the immunohistochemical localization of either monoclonal (Gros et al., 1985; Matsas et al., 1986; Pollard et al., 1987a, b, 1989a) or polyclonal (Barnes et al., 1988a) antibodies raised against the enzyme, confirmed these biochemical findings and provided detailed information concerning the topographic localization of enkephalinase in the rat and pig CNS. Radioautographic and immunohistochemical data also provided strong evidence for an association of the enzyme with selective neuronal populations. For example, distinct laminar distributions of enkephalinase activity were observed within the cerebral cortex, hippocampal formation, and gray matter of the spinal cord (Waksman et al., 1986a; Pollard et al., 1987b, 1989a), while selective immunolabeling patterns were detected at the level of certain brainstem nuclei (Pollard et al., 1989a). Also, intense enkephalinase activity was observed over fiber bundles linking the neostriatum to the globus pallidus, the entopeduncular nucleus, and the substantia nigra (Waksman et al., 1986b, 1987; Pollard et al., 1987b; Barnes et al., 1988a). Additional lines of evidence supporting the concept of a neuronal localization of enkephalinase include the presence of intense peptidase activity within synaptosomal membrane fractions (Alstein and Vogel, 1980; De la Baume et al., 1981) and the decrease of enkephalinase activity (Malfroy et al., 1979), enkephalinase immunoreactivity (Pollard et al., 1987b), and hinding of enkephalinase inhibitors (Waksman, 1986b, 1987) observed after intracerebral injections of neurotoxins.

Whether enkephalinase is also associated with glial components in the CNS remains a matter of controversy. The absence of enkephalinase immunoreactivity and of specific enkephalinase-inhibitor binding over major myelinated fiber bundles, such as the corpus callosum or the fornix, argues against an overall expression of the enzyme by oligodendrocytes. However, enkephalinase immunoreactivity has been observed over myelinated fascicles of the trigeminal nerve, as well as over Schwann cells in pig peripheral nerves (Matsas et al., 1986). Moreover, enkephalinase activity has been detected in primary cultures of astrocytes from the rat brain (Lentzen and Palenker, 1983) and has long been known to be associated in vivo with specialized glial elements, including choroid plexuses and ependymal cells (Gros et al., 1985; Schwartz et al., 1986a, b).

A recent electron microscopic immunocytochemical study of the globus pallidus of the pig has localized enkephalinase to the plasma membrane of axons and axon terminals, but not of dendrites or glial cells (Barnes et al., 1988b). Further ultrastructural studies in other brain regions and/or in different mammalian species are obviously needed to better document the cellular and subcellular distribution of this enzyme in the mammalian CNS. In the present study, the fine structural distribution of enkephalinase was investigated in the rat neostriatum by means of a specific monoclonal antibody (Ronco et al., 1986) previously used for detailed immunoradioautographic mapping of this enzyme in the rat CNS (Pollard et al., 1987a, b, 1989a). The antibody was used either in iodinated form and revealed using high resolution radioautography or in nonradioactive form and visualized by the PAP technique. The aim of our investigation was 3-fold: (1) to investigate whether the enzyme was selectively associated with neurons or was also present in glia,
(2) to determine whether it was confined to plasma membranes, and (3) to identify the neuronal and/or glial elements with which it was associated.

\section{Materials and Methods}

Monoclonal antibodies against enkephalinase. The present localization studies were performed using the IgG1 monoclonal mAb 85A2 in either iodinated or nonradioactive form. The antibody was raised by immunization of mice with rabbit kidney proximal tubule cells (Ronco et al., 1986), purified by ion-exchange chromatography, and iodinated (specific activity, $8 \mu \mathrm{Ci} / \mu \mathrm{g}$ ) by the chloramine $\mathrm{T}$ method as described elsewhere (McConahey and Dixon, 1966). The specificities of both iodinated and noniodinated forms of the antibody have been characterized in detail elsewhere (Pollard et al., 1987a; Ronco et al., 1988).

Effects of fixation on enkephalinase immunoreactivity. In a first series of experiments designed to assess the effects of fixation on enkephalinase antigenicity, adult male Sprague-Dawley rats $(180-200 \mathrm{gm} ; n=18)$ were anesthetized with chloral hydrate $(350 \mathrm{mg} / \mathrm{kg}$, i.p.) and perfused transcardially with a series of aldehyde mixtures in $0.1 \mathrm{M}$ Sorensen buffer (Table 1). All solutions were perfuscd at a temperature of $10-15^{\circ} \mathrm{C}$ through a manostat varistaltic pump at a flow rate of $150 \mathrm{ml} / \mathrm{min}$ for $3 \mathrm{~min}$ and of $75 \mathrm{ml} / \mathrm{min}$ for 4 additional $\mathrm{min}$. Immediately after perfusion, the brain was removed from the skull and postfixed by immersion in the same fixative for 1 or $2 \mathrm{hr}$ at room temperature (Table 1). It was then transferred overnight to a $30 \%$ sucrose solution in $0.1 \mathrm{M}$ Sorensen buffer and snap frozen by immersion in isopentane at $-40^{\circ} \mathrm{C}$ for $30 \mathrm{sec}$. Control animals were killed by decapitation, and their brains were immediately frozen as described. All brains were serially sectioned through the neostriatum on a cryostat. Sections ( $20 \mu \mathrm{m}$ thick) were mounted onto $2 \%$ gelatin-coated glass slides and directly incubated with $200 \mu \mathrm{l}$ of $\left({ }^{125} \mathrm{I}\right)$-iodinated monoclonal antibody ( ${ }^{125} \mathrm{I}-\mathrm{mAb} 85 \mathrm{~A} 2,5 \times$ $10^{5} \mathrm{cpm} / \mathrm{ml}$ ) diluted in $0.1 \mathrm{~m}$ phosphate buffer containing $0.2 \%$ BSA (pH 7.4) for $3 \mathrm{hr}$ at room temperature. The sections were then rinsed $3 \times 3 \mathrm{~min}$ in the same buffer, briefly washed in distilled water, air dricd under cool air, and radioautographed by apposition to tritium-sensitive film (Amersham). The films were developed in Kodak GBX after 3 days of exposure.

Immunoradioautography. For intraregional localization of the label, 5- $\mu \mathrm{m}$-thick cryostat sections from the neostriatum of fresh-frozen brains were first incubated with ${ }^{125} \mathrm{I}-\mathrm{mAb} 85 \mathrm{~A} 2$ as described above and then fixed for $30 \mathrm{~min}$ by immersion in a $4 \%$ solution of glutaraldehyde in $50 \mathrm{~mm}$ Sorensen buffer at room temperature. The sections were then dehydrated in graded ethanols, defatted in xylene, and rehydrated through an inverse series of ethanols. They were coated by dipping in Kodak NTB-2 nuclear emulsion diluted $1: 1$ in distilled water, developed in Dektol (Kodak) after 2 weeks of radioautographic exposure, and stained with Cresyl violet.

For cellular and subcellular localization of the label, animals $(n=6)$ were perfused with a mixture of $4 \%$ paraformaldehyde, $0.05 \%$ glutaraldehyde, and $0.2 \%$ picric acid, and the brain postfixed for 1 hr by immersion in the same fixative. The neostriatum was then blocked off and serially sectioned in the coronal plane with a vibrating microtome (Vibratome). Sections ( $30 \mu \mathrm{m}$ thick) were collected in cold $0.1 \mathrm{M}$ phosphate buffer, rinsed in the same buffer containing $0.2 \% \mathrm{BSA}$, and incubated with ${ }^{125} \mathrm{I}-\mathrm{mAb} 85 \mathrm{~A} 2\left(5 \times 10^{5} \mathrm{cpm} / \mathrm{ml}\right)$ for $3 \mathrm{hr}$ at room temperature. For rapid assessment of the immune reaction, a few sections were mounted onto gelatinized glass slides and radioautographed by apposition to tritium-sensitive film. All other sections were postfixed for $1 \mathrm{hr}$ with $2 \% \mathrm{OsO}_{4}$ in $0.1 \mathrm{M}$ phosphate buffer containing $7 \%$ dextrose, stained en bloc with $2 \%$ uranyl acetate for $1.5 \mathrm{hr}$, dehydrated in graded ethanols, and flat-embedded in Epon between plastic coverslips. The sections were then trimmed to sample the dorsal-lateral quadrant of the neostriatum and reembedded in Beem capsules.

For light microscopy, semithin sections ( $1 \mu \mathrm{m}$ thick) were cut from the surface of each capsule, collected on acid-washed glass slides, coated by dipping in Kodak NTB-2 nuclear emulsion diluted 1:1 in distilled water, and developed in D-19 after 6 weeks of radioautographic exposure.

For electron microscopy, sections ( $80 \mathrm{~nm}$ thick) were cut from the same Epon blocks, collected on parlodion-coated slides, double stained with uranyl acetate and lead citrate, carbon coated, and radioautographed by dipping into Ilford L4 emulsion diluted 1:4 in distilled water. After 10 weeks of exposure, the radioautograms were developed in Kodak D-19 (1 min at $\left.20^{\circ} \mathrm{C}\right)$, fixed in $30 \%$ sodium thiosulfate $(10 \mathrm{~min}$ 
Table 1. Efrects of tissue fixation on enkephalinase antigenicity

\begin{tabular}{lll} 
Histoprocessing & $\begin{array}{l}\text { Duration } \\
\text { of post- } \\
\text { fixation }\end{array}$ & $\begin{array}{l}\text { Immuno- } \\
\text { reactivity }\end{array}$ \\
\hline $\begin{array}{l}\text { Unfixed } \\
4 \% \text { paraformaldehyde }\end{array}$ & - & +++ \\
$\begin{array}{l}4 \% \text { paraformaldehyde } / 0.2 \% \\
\text { glutaraldehyde }\end{array}$ & $1 \mathrm{hr}$ & +++ \\
$\begin{array}{l}4 \% \text { paraformaldehyde } / 0.5 \% \\
\text { glutaraldehyde } / 0.2 \% \text { picric acid }\end{array}$ & - & + \\
$\begin{array}{l}4 \% \text { paraformaldehyde } / 0.05 \% \\
\text { glutaraldehyde } / 0.2 \% \text { picric acid }\end{array}$ & $1 \mathrm{hr}$ & + \\
$\begin{array}{c}4 \% \text { paraformaldehyde } / 0.05 \% \\
\text { glutaraldehyde } / 0.2 \% \text { picric acid }\end{array}$ & $2 \mathrm{hr}$ & +++ \\
\hline
\end{tabular}

"By immersion in the same fixative mixture.

"Semiquantitative estimates from 0 to +++ .

at $20^{\circ} \mathrm{C}$ ), picked up on bare 200 mesh copper grids, and examined with a Jeol $100 \mathrm{CX}$ electron microscope after the parlodion membrane was thinned in amyl acetate.

Analysis of the radioautograms. Quantitative analysis of electron microscopic radioautogorams was carried out in 1 thin section from each animal $(n=6)$. In each case, 1 grid square $\left(0.1 \mathrm{~mm}^{2}\right)$ was systematically scanned and every labeled site photographed at an initial magnification of $10,000 \times$. The distribution of silver grains was analyzed using a $50 \%$ probability circle method modified from Williams (1969) and described in detail elsewhere (Hamel and Beaudet, 1987; Dana et al., 1989). The diameter of the resolution circle was determined after Blackett and Parry (1977) (3.4 $\times$ half distance) using a half distance (HD) of $90 \mathrm{~nm}$ (Salpeter et al., 1978). The resolution circles, drawn on a transparent overlay, were centered over each grain $(n=610)$, and every structure (exclusive grains) or combination of structures (shared grains) included therein was recorded and tabulated. A population of hypothetical grains $(n=$ 2345) was then created by superimposing over the same series of micrographs a regular array of resolution circles of the same diameter as the ones used to score real grains. The distribution of these hypothetical grains was then compared with that of real grains using a $\chi^{2}$ test. To reduce the number of compartments in the analysis, grains originally ascribed to 3-structure compartments were redistributed within 2-structure ones according to the original labeling frequency of each pair of structures seen within the resolution circle. In a further analysis, grains overlying 2 or more profiles of which 1 could not be identified were redistributed within compartments containing those elements that were identified proportionally to their original labeling frequency.

Immunocytochemistry. In 4 other animals perfused with a mixture of $4 \%$ paraformaldehyde, $0.05 \%$ glutaraldehyde, and $0.2 \%$ picric acid, the brains were postfixed by immersion for $1 \mathrm{hr}$ in the same fixative and processed for double-bridge peroxidase-antiperoxidase immunocytochemistry. Vibratome-cut sections ( $30 \mu \mathrm{m}$ thick) from the neostriatum were incubated with nonradioactive $\mathrm{mAb} 85 \mathrm{~A} 2(3.5 \mathrm{mg} / \mathrm{ml}$ diluted 1:2000 in $0.1 \mathrm{~m}$ phosphate buffer containing $0.2 \% \mathrm{BSA}$ ) for $3 \mathrm{hr}$ at room temperature, rinsed $3 \times 3 \mathrm{~min}$ in the same buffer, and sequentially incubated at room temperature with: (1) a 1:50 dilution of goat antimouse IgGs (ICN Immuno-Biomedicals) for $30 \mathrm{~min}$, and (b) a 1:500 dilution of monoclonal mouse (PAP) complex (ICN Immuno-Biomedicals), also for $30 \mathrm{~min}$. These 2 steps were then repeated. All dilutions and rinses $(2 \times 8 \mathrm{~min}$ between each step) were made in $0.1 \mathrm{M}$ phosphate buffer containing $0.2 \% \mathrm{BSA}$. Control sections were processed in parallel, leaving out the primary antibody. The peroxidase was reacted for $6 \mathrm{~min}$ with $0.05 \% 3-3^{\prime}$-diaminobenzidine in $0.1 \mathrm{~m}$ Tris- $\mathrm{HCl}$ buffer containing $0.01 \% \mathrm{H}_{2} \mathrm{O}_{2}$. The sections were then briefly rinsed in distilled water and processed for either light or electron microscopy.

For light microscopy, the sections were mounted onto gelatin-coated slides, dehydrated in graded ethanols, defatted in xylene, and coverslipped.

For electron microscopy, the sections were postfixed for $1 \mathrm{hr}$ with $2 \%$ $\mathrm{OsO}_{4}$ in $0.1 \mathrm{M}$ phosphate buffer containing $7 \%$ dextrose, dehydrated in graded ethanols, and flat-embedded in Epon between 2 plastic coverslips. After a first polymerization, the sections were trimmed down to size and reembedded in Beem capsules. Following further polymerization, the blocks were trimmed and silver-gold thin sections were cut from their surface with an ultramicrotome (Reichert) and collected on bare 200 mesh copper grids. All sections were sampled from the dorsolateral caudoputamen and included at least 1 patch of high labeling density. They were then stained with $2.5 \%$ uranyl acetate diluted in $50 \%$ ethanol and examined with a JEOL $100 \mathrm{CX}$ electron microscope.

\section{Results}

\section{Light microscopy}

Film radioautograms of $20-\mu \mathrm{m}$-thick fresh-frozen sections incubated with ${ }^{125} \mathrm{I}-\mathrm{mAb} 85 \mathrm{~A} 2$ antibodies exhibited intense immunostaining throughout the neostriatum, nucleus accumbens, and globus pallidus (Fig. la). In the neostriatum, the labeling spared the myelinated fascicles of the internal capsule and was characteristically more intense in the ventrolateral as opposed to the dorsomedial aspect of the structure (Fig. 1a). In addition, small and irregular patches of intense immunoreactivity were occasionally apparent against the dense matrix staining. Labeling in the nucleus accumbens and globus pallidus was uniformly dense throughout.

Sections fixed with a mixture of $4 \%$ paraformaldehyde, $0.2 \%$ picric acid, and $0.05 \%$ glutaraldehyde exhibited a labeling pattern comparable in density and distribution to that observed in fresh-frozen material, provided that the tissue had not been postfixed by immersion for more than $1 \mathrm{hr}$ (Fig. $1 \mathrm{~b}$, Table 1 ). In sections postfixed for longer periods of time or fixed with an aldehyde mixture containing higher concentrations of glutaraldehyde, the immunolabeling was either substantially reduced or virtually abolished (lable 1).

In 5 - $\mu \mathrm{m}$-thick sections radioautographed according to conventional dipping techniques, the distribution of cnkcphalinase immunoreactivity was similar to that observed in film radioautograms, except for the patches of dense immunoreactivity, which stood out more clearly against the background staining (Fig. 1c). These patches were most apparent in the dorsal aspect of the neostriatum and usually engulfed 1 or several myelinated fiber bundles. A streak of intense immunolabeling was also apparent immediately beneath the corpus callosum (Fig. $1 c$ ). The nucleus accumbens, globus pallidus, and ventral tier of the neostriatum appeared as intensely and homogeneously labeled as in the film radioautograms.

Twenty- $\mu$ m-thick, aldehyde-fixed sections reacted with PAP/ $\mathrm{DAB}$ exhibited an immunolabeling pattern comparable to that seen in radioautographically processed material (Fig. 1d). In particular, patches of intense immunoreactivity, as well as a dense subcallosal immunoreactive streak, were apparent throughout the dorsal aspect of the nucleus (Fig. 1d). Also as in radioautograms, the labeling was more homogeneous and more intense within the ventrolateral tier of the neostriatum and adjoining nucleus accumbens than in the dorsomedial aspect of the structure.

In light microscopic radioautograms from $1-\mu \mathrm{m}$-thick sections taken from the surface of ${ }^{125} \mathrm{I}$-mAb 85A2-incubated slices, the label was detected in the form of individual silver grains scattered over the neuropil. As in the frozen sections, islands of dense immunostaining were prominent against zones of weaker immunoreactivity (Fig. 2a). At high magnification, the label was found to pervade the entire neuropil but selectively spare the cytoplasm of cross-sectioned neuronal perikarya (Fig. $2 b$ ). Occasionally, however, silver grains were detected alongside the plasma membrane of neuronal perikarya and/or proximal dendrites (Fig. 2c). Only sparse silver grains were apparent over 



Figure 1. Regional distribution of enkephalinase immunoreactivity in sections of rat neostriatum. $a$ and $b$, Film radioautograms from $20-\mu \mathrm{m}$-thick fresh $(a)$ and aldehyde-fixed $(b)$ frozen sections incubated with ${ }^{125} \mathrm{I}-\mathrm{mAb} 85 \mathrm{~A} 2$. Both sections exhibit comparable labeling patterns. In the neostriatum, the labeling is more pronounced ventrolaterally than medially. Note the presence of ill-defined patches of high labeling density (arrows). c , Radioautogram of a 5 - $\mu \mathrm{m}$-thick fresh-frozen section incubated with ${ }^{125} \mathrm{I}-\mathrm{mAb} 85 \mathrm{~A} 2$ and processed using conventional dipping techniques (dark field). The labeling shows the same lateromedial gradient as on film. However, the patches of high labeling density (arrows) stand out much more clearly against the matrix labeling. The ventral pallidum $(V P)$ is also labeled. $d$, PAP/DAB-immunoreacted $30-\mu \mathrm{m}$-thick aldehyde-fixed, vibratome-cut section incubated with cold $\mathrm{mAb} 85 \mathrm{~A} 2$. The pattern of enkephalinase immunoreactivity is comparable to that observed in radioautograms. Here again, dense patches (arrows) are visible against a less intensely reactive matrix. Scale bar, $750 \mu \mathrm{m}$. cc, corpus callosum; ac, anterior commissure. fibers of the internal capsule. Intraparenchymal blood vessels were usually devoid of labeling.

\section{Electron microscopy}

In electron microscopic radioautograms from ${ }^{125} \mathrm{I}-\mathrm{mAb} 85 \mathrm{~A} 2-$ incubated sections, the radioactivity was detected in the form of isolated silver grains scattered over the neuropil. By probability circle analysis, approximately $90 \%$ of these grains were found to overlie 2 or more apposed cellular elements (shared grains). The remaining $10 \%$ were found inside neuronal or glial structures (exclusive grains; Table 2), though often at a short distance (albeit longer than the radius of the resolution circle) from a plasma membrane. This distribution was significantly different $(p \leq 0.001)$ from that of uniformly dispersed hypothetical grains of which more than $25 \%$ were classified as exclusive (Table 2).
As can be seen in Table 2, the vast majority of shared grains was associated with neuronal interfaces, implicating the plasma membrane of dendritic shafts, branchlets, or spines (Figs. 3-5). In fact, after repartition of unknowns (and normalization to 100; see Table 3), axo-dendritic (Figs. $3 a ; 4, a, e ; 5, a-c$ ), dendrodendritic (Figs. 3b, 4a), and dendro-glial (Fig. 4b) interfaces together accounted for almost $65 \%$ of the shared grains. However, comparison with similarly analyzed hypothetical grains indicated that interfaces involving dendrites also showed the highest frequency of occurrence in tissue (60\%; Table 3). Dendrite-associated grains were usually seen in isolation, though several could be associated with a single dendritic profile (Figs. $3 c, 4 a$ ). Most were detected at the level of appositions with axon terminals (Table 2, Figs. 3-5), 15\% of which exhibited a synaptic specialization in the plane of section (Table 3, Fig. 5). This synaptic labeling frequency was approximately half that of uni- 
Figure 2. Light microscopic radioautograms of a $1-\mu \mathrm{m}$-thick, plasticembedded section taken from the surface of a striatal slice incubated with ${ }^{125} \mathrm{I}-\mathrm{mAb}$ 85A2. $a$, Dark field. A labeled striosome $(S)$ is visible next to the less intensely immunoreactive matrix $(M)$. Scale bar, $300 \mu \mathrm{m} . b$ and $c$, Bright field. Silver grains are scattered over the neuropil, sparing neuronal perikarya. Occasionally, they are seen aligned along the plasma membrane of perikarya and/ or proximal dendrites (arrows). Only sparse silver grains are detected over myelinated fascicles of the internal capsule $(I C)$. Scale bars, $20 \mu \mathrm{m}$.
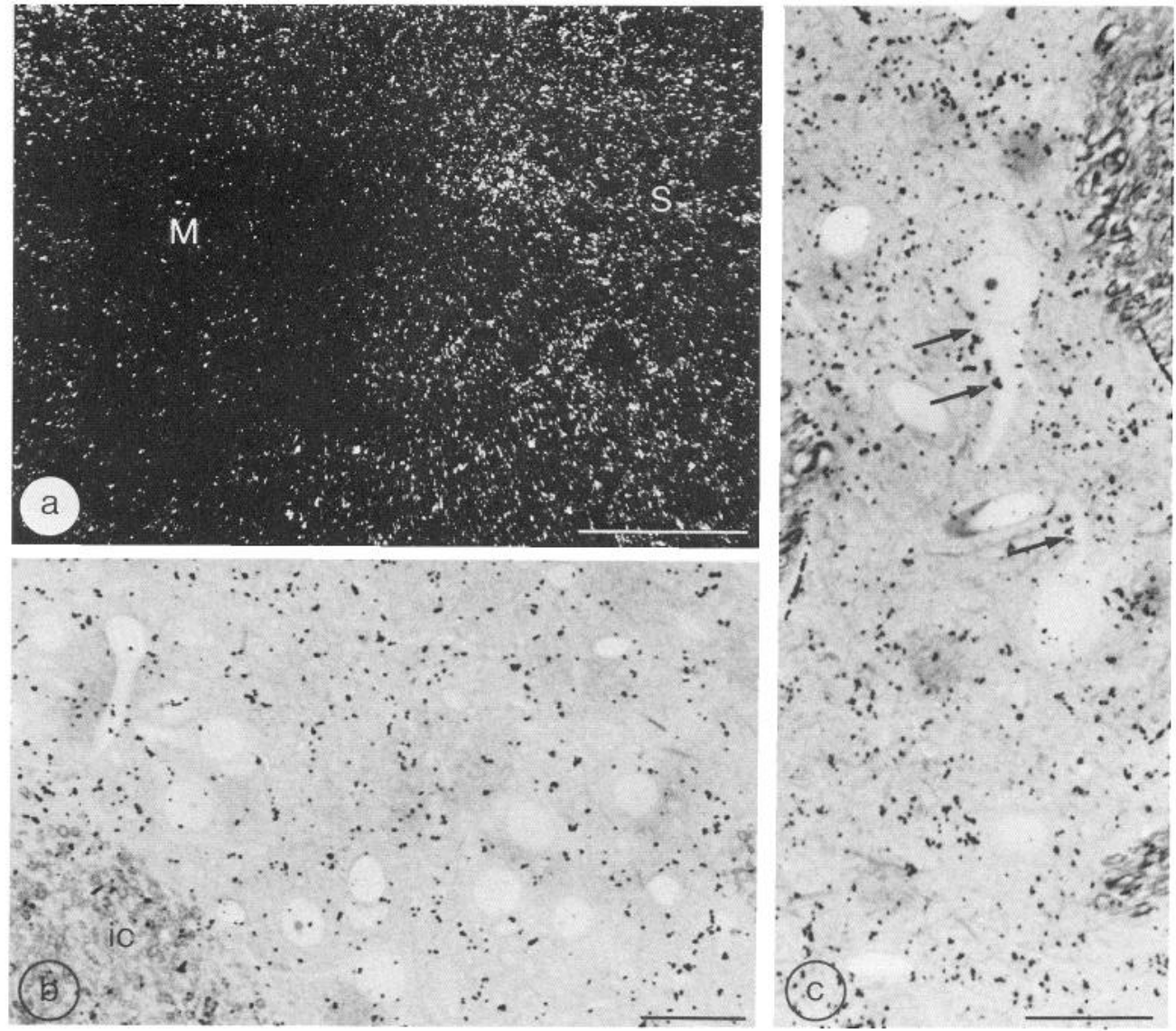

Table 2. Electron microscopic radioautographic distribution of enkephalinase immunoreactivity in the rat neostriatum

\begin{tabular}{|c|c|c|}
\hline Tissue compartments & Real grains & $\begin{array}{l}\text { Hypotheti- } \\
\text { cal grains }\end{array}$ \\
\hline \multicolumn{3}{|l|}{ Exclusive grains } \\
\hline Dendrite & 4.3 & 12.7 \\
\hline Axon terminal & 0.8 & 5.0 \\
\hline Axon $^{a}$ & 1.0 & 0.4 \\
\hline Myelinated axon & 0.5 & 1.7 \\
\hline Soma & 2.7 & 4.2 \\
\hline Glia & 1.3 & 1.4 \\
\hline \multicolumn{3}{|l|}{ Shared grains } \\
\hline Dendrite/dendrite & 5.1 & 5.7 \\
\hline Dendrite/axon terminal & 18.8 & 15.1 \\
\hline Dendrite/axon & 9.6 & 12.5 \\
\hline Dendrite/glia & 1.5 & 0.2 \\
\hline Axon terminal/axon terminal & 2.3 & 2.6 \\
\hline Axon terminal/axon & 5.7 & 8.3 \\
\hline Axon terminal/glia & 2.0 & 0.4 \\
\hline Axon/axon & 3.7 & 6.0 \\
\hline Axon/glia & 2.7 & 1.5 \\
\hline Myelinated axon/myelin sheath & 4.3 & 4.1 \\
\hline Unidentified $^{b}$ & 26.7 & 11.7 \\
\hline Others $^{c}$ & 7.0 & 6.5 \\
\hline
\end{tabular}

Results are expressed as \% of total $(n=6)$; number of real grains counted, 610 ; number of hypothetical grains counted, 2345. Distribution of real grains significantly different from that of hypothetical grains, with $p<0.001$.

${ }^{a}$ Refers to unmyelinated axons throughout.

${ }^{b}$ One of the apposed elements not identified.

- Unidentified single elements and categories containing less than $1 \%$ of the shared grains. formly distributed hypothetical shared grains (28\%). Labeled synapses were usually of the asymmetrical variety (Fig. 5). Typically, the label did not overlie the synaptic density itself but lay immediately adjacent to it (Fig. 5, $a, b$ ).

A significant proportion of the silver grains was associated with interfaces between axon terminals and nondendritic ele-

\begin{tabular}{lcc}
\hline $\begin{array}{l}\text { Table 3. Radioautographic distribution of enkephalinase } \\
\text { immunoreactivity in rat neostriatum: Distribution of shared grains } \\
\text { after mathematical redistribution of grains in unidentified } \\
\text { compartments }\end{array}$ & \\
& & \\
& Real grains & $\begin{array}{l}\text { Hypotheti- } \\
\text { cal grains }\end{array}$ \\
Tissue compartments & 9.3 & 10.2 \\
\hline Dendrite/dendrite & & \\
Dendrite/axon terminal & 5.4 & 7.8 \\
Synaptic & 30.0 & 20.4 \\
$\quad$ Nonsynaptic & 16.9 & 21.0 \\
Dendrite/axon & \\
Dendrite/glia & 2.7 & 0.5 \\
Axon terminal/axon terminal & 4.4 & 5.1 \\
Axon terminal/axon & 10.3 & 14.6 \\
Axon terminal/glia & 3.8 & 0.8 \\
Axon/axon & 6.2 & 9.6 \\
Axon/glia & 4.6 & 2.8 \\
Myelinated axon/myelin sheath & 6.3 & 7.2 \\
\hline
\end{tabular}

Data are expressed as percentage of shared grains. Distribution of real grains was significantly different from that of hypothetical grains, with $p<0.001$.

${ }^{a}$ Axon refers to unmyelinated axons throughout. 

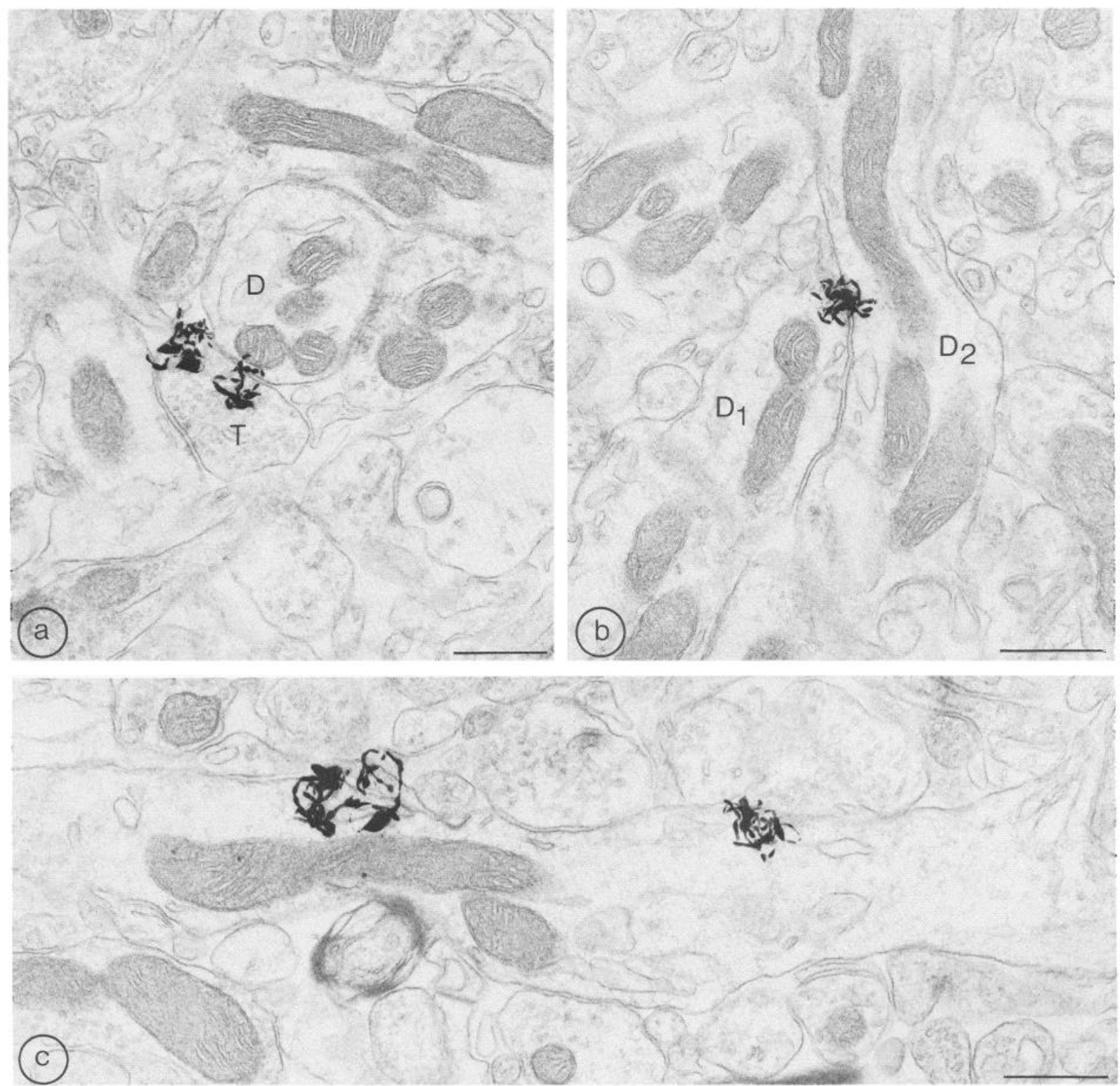

Figure 3. Electron microscopic radioautograms from sections of rat neostriatum incubated with ${ }^{125} \mathrm{I}-\mathrm{mAb} 85 \mathrm{~A} 2$. $a$, Labeled axo-dendritic contact. Two silver grains overlie the plasma membranes of an axon terminal $(T)$ and abutting cross-sectioned dendrite $(D)$. No synaptic specialization is apparent at the site of labeling. $b$, Silver grain localized at the interface between 2 dendritic shafts $(D 1, D 2)$. $c$, Dendritic shaft showing 2 different labeled loci along its plasma membrane. The 2 grains on the left are facing an axially oriented unmyelinated axon, and the grain on the right is located at the level of an axon terminal. Scale bars, $0.5 \mu \mathrm{m}$.

ments, namely other axon terminals (Fig. 4, $a, c, e, f$ ), small unmyelinated axons, and astrocytic leaflets (Table 2). As a whole, the labeling frequency of these different compartments was comparable to that observed in the case of hypothetical shared grains (Table 3). Labeled unmyelinated axons were usually small and often ran in bundles amongst myelinated ones (Fig. $4 d$ ). In some instances, they were partially filled with synaptic vesicles, which made it difficult to differentiate them from axonal varicosities.

Approximately $5 \%$ of both real and hypothetical grains were associated with myelinated axons (Table 2, Fig. $4 c$ ). In both cases, the grains were localized mainly at the interface between the axonal membrane and the inner leaflet of the myelin sheath (Fig. 4c). A few also overlaid the membrane of unmyelinated axons lying immediately adjacent to the outer leaflet of myelinated ones.
Finally, neuronal cell bodies were only rarely labeled, and silver grains detected over their membrane showed no obvious predilection for any given abutting element.

In thin sections from PAP-reacted material, enkephalinase immunoreactivity was detected in the form of an electron-dense precipitate bordering neuronal and glial plasma membranes (Fig. $6, a, b)$. By contrast, sections incubated in the absence of primary antibody showed no apparent intensification of plasma membranes (Fig. 6c). The overall pattern of immunostaining was characterized by the juxtaposition of fields in which most cellular profiles showed some degree of immunolabeling interrupted by zones that were virtually label-free. Labeled elements included medium-sized nerve cell bodies (Fig. 7a), dendritic shafts, branchlets, and spines (Figs. 6-8), axon terminals (Figs. 6-8), and cross-sectioned unmyelinated axons (Fig. 6, $a, b$ ). 

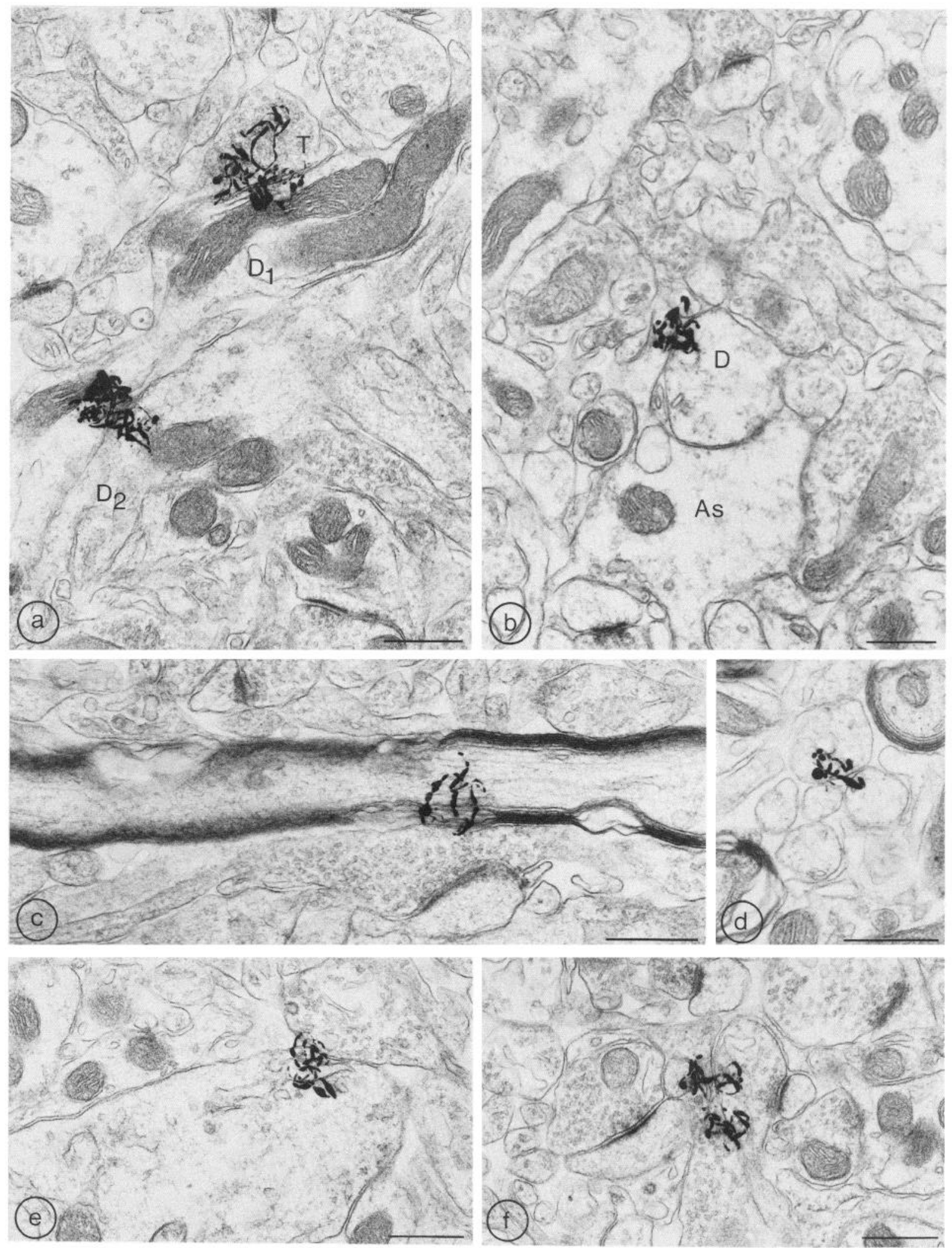

Figure 4. Electron microscopic radioautograms from sections of rat neostriatum incubated with ${ }^{125} \mathrm{I}-\mathrm{mAb} 85 \mathrm{~A} 2$. a, Longitudinally sectioned dendritic shaft $(D 1)$ showing 2 different labeled loci along its plasma membrane. The upper grains also overlap a vesicle-filled axonal varicosity $(T)$. The lower grains are seen opposite a second dendritic shaft $(D 2)$. $b$, The probability circle associated with this silver grain includes a crosssectioned dendrite $(D)$ and an ensheathing astrocytic process $(A s), c$, Silver grain located at the interface between a longitudinally sectioned axon and its myelin sheath. $d$, Small bundle of labeled unmyelinated axons running among myelinated ones. $e$, Silver grain lying at a nondifferentiated axo-dendritic interface. $f$, Labeled axo-axonic interfaces. The 2 grains overlap adjacent varicose axons. The varicosity on the right establishes a synaptic contact with a small dendritic spine. In the case of the upper grain, the resolution circle also encompasses a small cross-sectioned dendritic spine. Scale bars, $0.5 \mu \mathrm{m}$. 

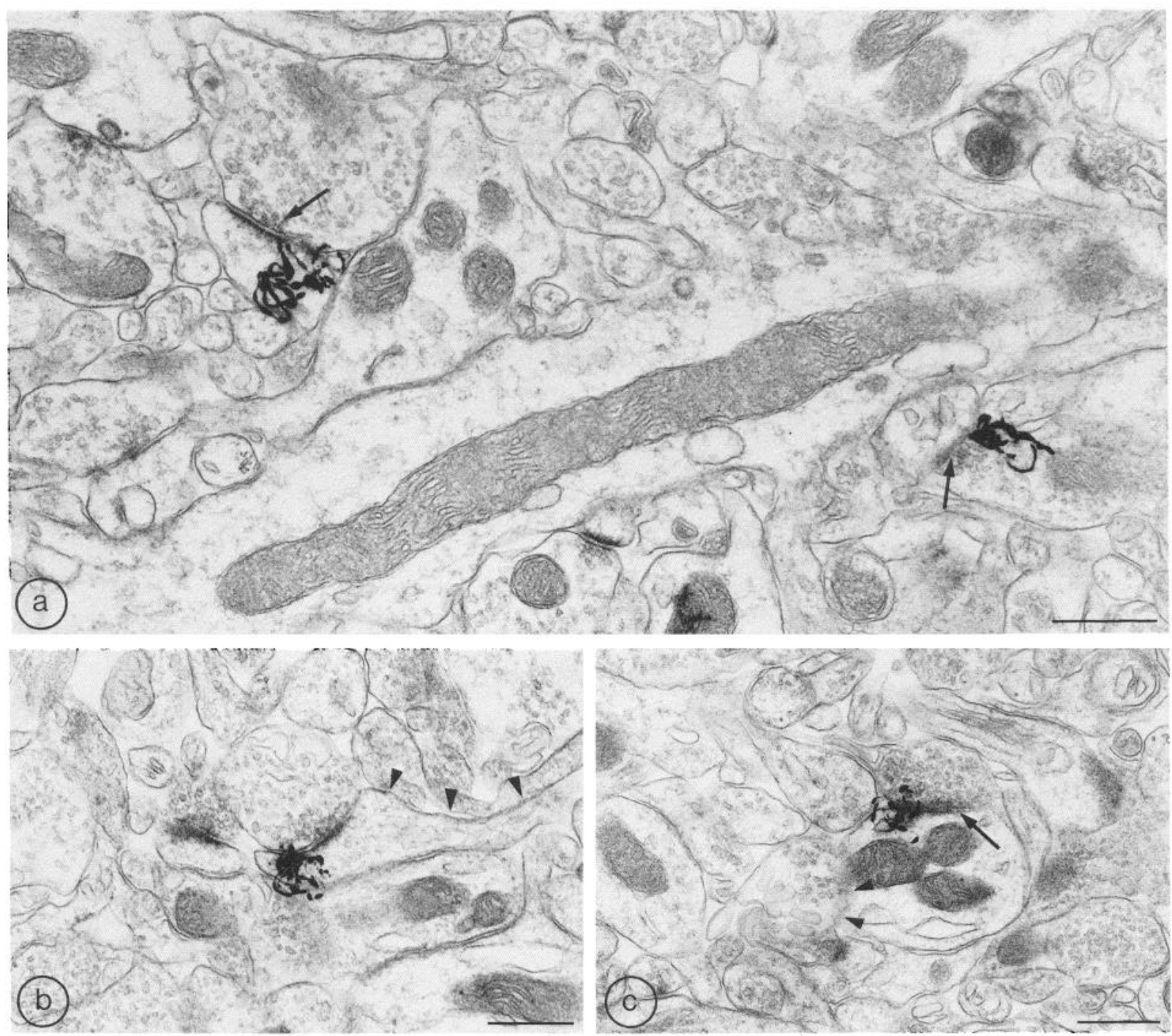

Figure 5. Electron microscopic radioautograms from sections of rat neostriatum incubated with ${ }^{125} \mathrm{I}$-mAb $85 \mathrm{~A} 2$, showing labeled axo-dendritic synapses. All labeled synapses are of the asymmetrical variety (arrows). Synapses in $a$ are established on dendritic branchlets or cross-sectioned spines. The labeled synapse in $b$ is established on the tip of a slender thorn (arrowheads) and, in $c$, on a cross-sectioned dendritic shaft which also receives an unlabeled contact (arrowheads). Scale bars, $0.5 \mu \mathrm{m}$.

More rarely, immunoreactivity was also apparent along the plasma membrane of oligodendrocytes (Fig. $8 d$ ) or of thin, astrocytic leaflets (Fig. 8a). When labeled, neuronal or glial profiles usually showed immunoreactive deposits along most of their contour (Figs. 7, $a, b ; 8 c$ ). However, the density of the reaction product was usually the highest along those parts of the membrane directly apposing another labeled element (Figs. 7, $c, d ; 8, a, b$ ). At high magnification, these labeled interfaces were quite distinct, and the intervening extracellular space was usually devoid of immunoprecipitate (Fig. $8, a-c$ ). The reaction product also appeared interrupted, giving the labeled membranes a dashedline appearance (Fig. 8, $a-c$ ). This effect was further enhanced by the parallelism of dashes and spaces along opposite membranes (Fig. $8 b$ ).

The presence or absence of immunoreactivity at the level of synaptic junctions was difficult to ascertain, given the natural electron density of synaptic specializations in DAB-reacted material. However, there was no obvious increase in either the width or the density of membrane differentiations at the level of synaptic contacts (Figs. 6, $a, b ; 8 a$ ).

\section{Discussion}

Topographic distribution of enkephalinase immunoreactivity Although raised against rabbit kidney, the IgG1 monoclonal antibody used in the present study for light and electron microscopic visualization of enkephalinase had previously been shown to react with rat brain enkephalinase (Pollard et al., 1987a, b; Ronco et al., 1986, 1988). Accordingly, the regional distribution of the enzyme, as assessed here by immunoradioautography in unfixed sections of rat basal ganglia, broadly conformed to that previously observed by immunohistochemistry using the same antibody (Pollard et al., 1989a) or by radioautography after binding of the tritiated inhibitors of the enzyme ${ }^{3} \mathrm{H}-\mathrm{HA}$ COB-gly or ${ }^{3} \mathrm{H}$-thiorphan (Waksman et al., 1986a, b; Pollard et al., 1987b). The presence of dense enkephalinase immunolabeling in the neostriatum, nucleus accumbens, and ventral pallidum was also in keeping with the results of earlier biochemical assays that had shown an intense activity of the enzyme within these areas (Llorenz-Cortes et al., 1982; Malfroy et al., 1979).

Within the neostriatum, patches of high enkephalinase im- 

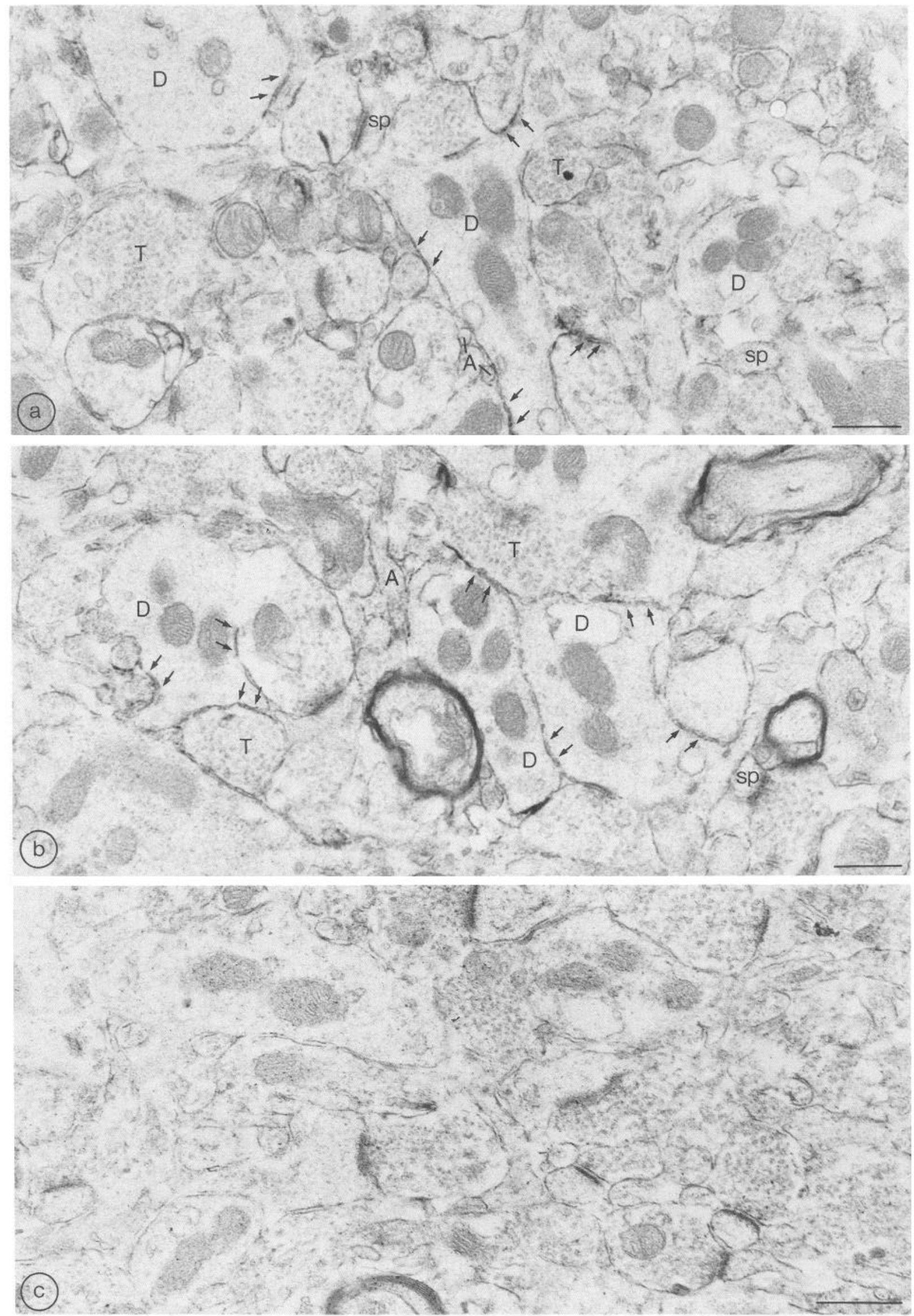

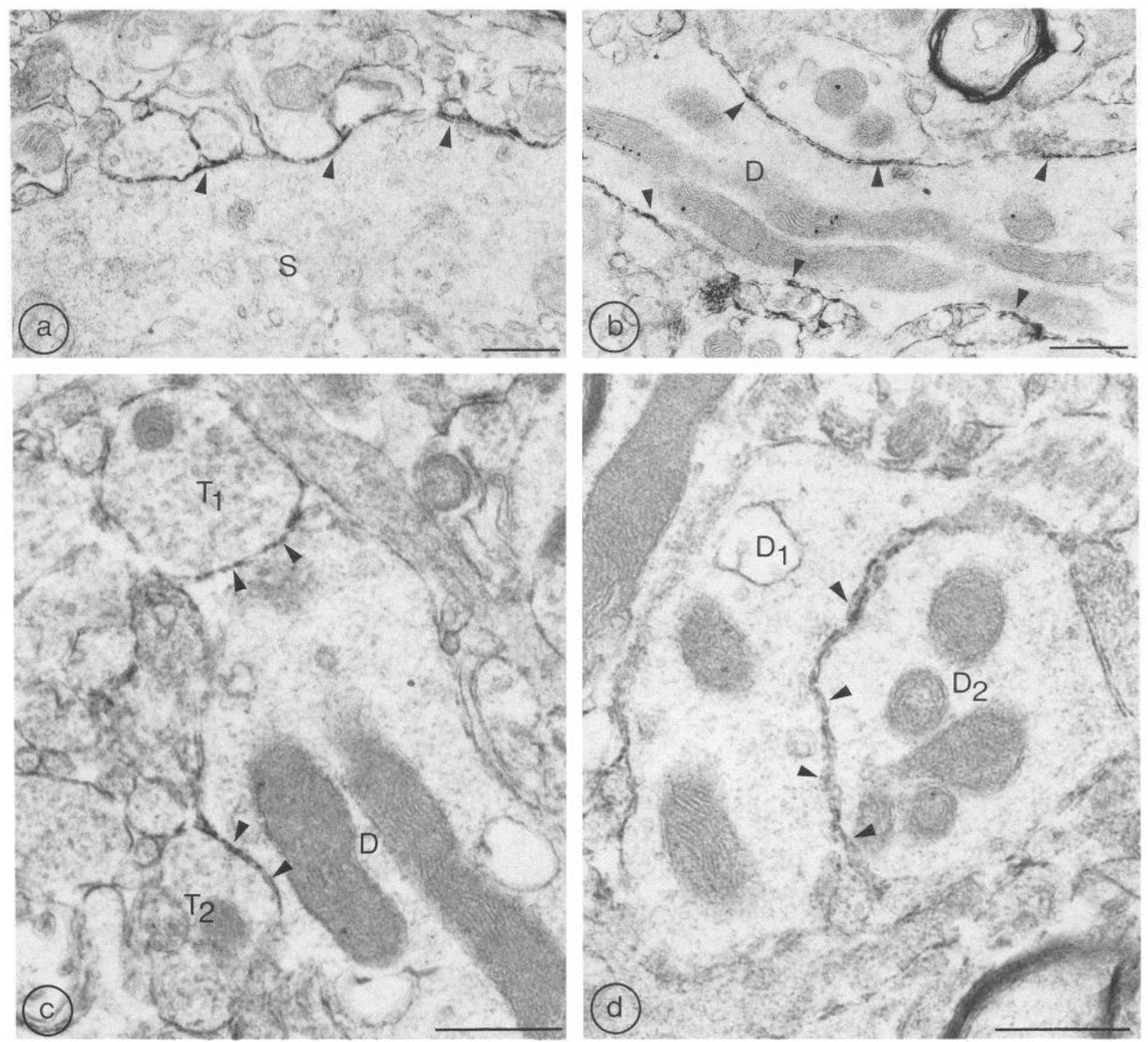

Figure 7. Electron microscopic localization of enkephalinase immunoreactivity revealed by the PAP method. The immunoreactivity is detected in the form of an electron-dense precipitate bordering plasma membranes. $a$, A dense PAP deposit (arrowheads) is visible along the plasma membrane of a nerve cell body $(S)$. Note that abutting elements are also labeled at the site of apposition. $b$, Cross-sectioned dendritic shaft $(D)$ showing a similar pattern of immunolabeling. $c$ and $d$, Immunoreactive dendritic shafts $(D)$. The immunostaining is most pronounced (arrowheads) at the interface with labeled axon terminals $(c, T 1, T 2)$ or other labeled dendrites $(d, D 1, D 2)$. Scale bars, $0.5 \mu \mathrm{m}$.

munoreactivity were apparent against an already fairly dense matrix labeling. These patches were most evident in 5 - $\mu$ m-thick sections radioautographed by dipping, but were also discernible in DAB-reacted material and in film radioautograms, provided that these were developed after a short duration of exposure. Indeed, prolongation of the radioautographic exposure resulted in a loss of contrast between patches and matrix, which probably explains why these zones of higher immunoreactivity had previously escaped detection in the rat. They had, however, been described in the pig, where they were found to correspond to acetylcholinesterase-poor striatal compartments (i.e., striosomes; Barnes et al., 1988a). Preliminary observations in the rat suggest that in this species, as well, patches of dense enkephalinase immunoreactivity correspond to striosomes, as defined by mu opioid receptor binding (Marcel et al., 1989).

Fixation of the tissue with glutaraldehyde significantly reduced enkephalinase immunoreactivity in all regions examined. This loss of immunoreactivity was more pronounced as concentrations of glutaraldehyde were increased in the fixation medium. However, this loss was already apparent following pro-

Figure 6. Electron microscopic localization of enkephalinase immunoreactivity revealed by the PAP method. The immunoreactivity is detected in the form of an electron-dense precipitate bordering plasma membranes. $a$ and $b$, Dendritic shafts $(D)$, dendritic spines $(s p)$, axon terminals $(T)$, and small cross-sectioned axons $(A)$ in a field of enkephalinase immunolabeling. Note that the immunoreactivity is more pronounced over certain elements than over others and that the labeling is often interrupted along labeled processes (arrows). $c$, Control section processed by omitting the primary antibody. Note the absence of membrane densification except at the level of synaptic junctions. Scale bars, $0.5 \mu \mathrm{m}$. 

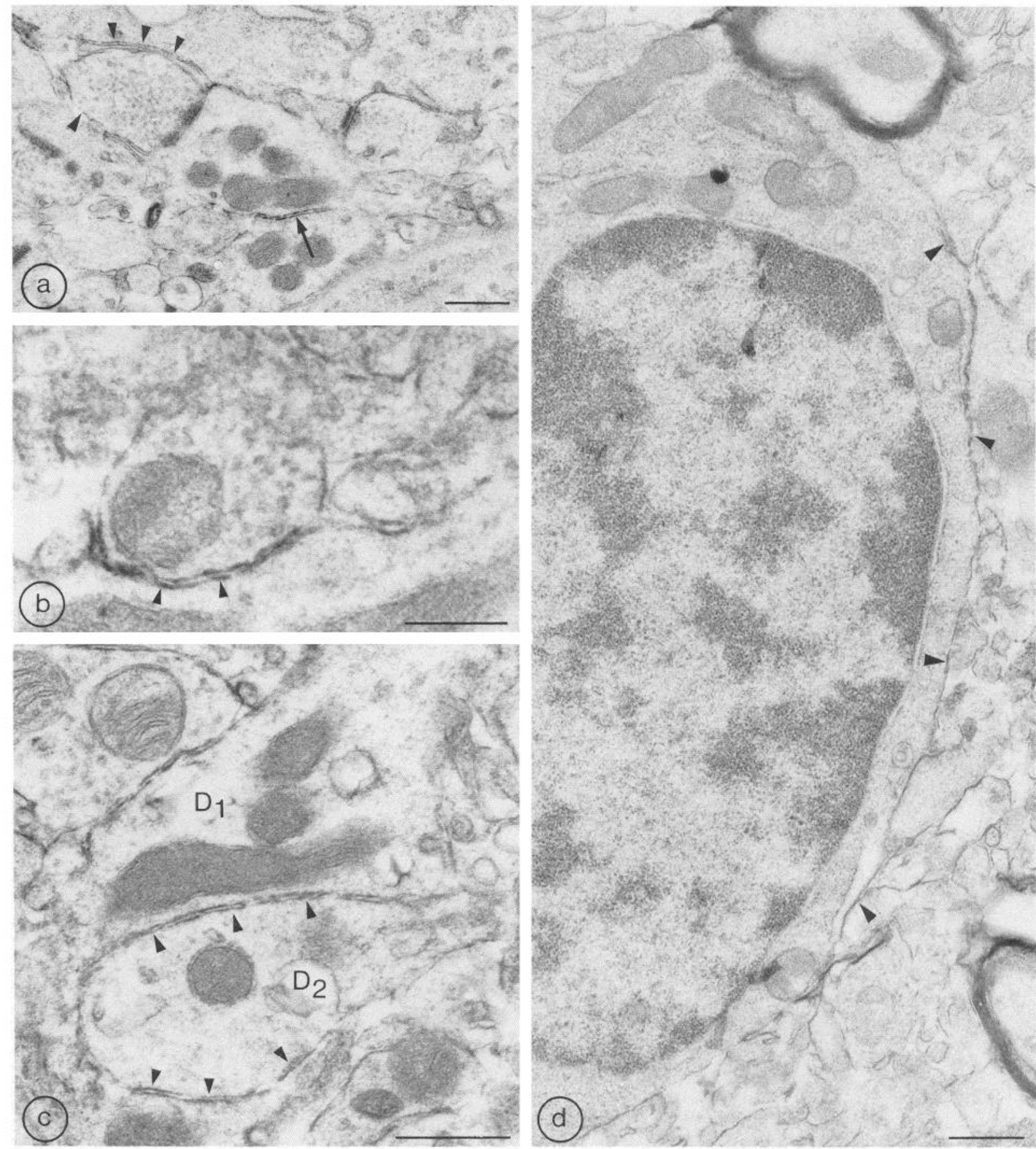

Figure 8. Electron microscopic localization of enkephalinase immunoreactivity revealed by the PAP method. The immunoreactivity is detected in the form of an electron-dense precipitate bordering plasma membranes. $a$, Intensely labeled dendro-dendritic interface (arrow). Note the absence of reaction product in the intercellular space. One of the labeled dendrites is contacted by an axon terminal ensheathed by a thin, densely immunoreactive glial leaflet (arrowheads). Scale bar, $0.5 \mu \mathrm{m}$. $b$, Labeled axo-dendritic interface seen at high magnification. Note that the reaction product is interrupted, giving each of the apposed membranes a dashed-line appearance. This effect is enhanced by the parallelism of dashes and spaces along the two elements (arrowheads). Scale bar, $0.25 \mu \mathrm{m}$. $c$, Two apposed dendritic elements $(D 1, D 2)$ show intense enkephalinase immunoreactivity along most of their contour (arrowheads). Scale bar, $0.5 \mu \mathrm{m}$. $d$, Oligodendrocyte showing zones of moderate immunostaining along its plasma membrane (arrowheads). Scale bar, $0.5 \mu \mathrm{m}$.

longed postfixation in solutions containing only low concentrations of the aldehyde. This effect may result from a structural modification of the ectoenzyme secondary to crosslink with glutaraldehyde, as previously reported for other tissue antigens (see Beaudet and Descarries, 1987). It could also reflect reduced accessibility of antigenic sites due to improved tissue preservation. The topographic distribution of enkephalinase immunoreactivity in sections fixed with low concentrations of glutaraldehyde and postfixed for $1 \mathrm{hr}$ or less was similar to that observed in unfixed material. The intensity of the staining was usually slightly lower than in fresh tissue sections, again presumably due to a loss or reduced accessibility of antigenic sites 
secondary to the use of glutaraldehyde. The background staining was comparable to that observed in fresh-frozen material, which suggests that the antibody reacts poorly with free aldehyde groups.

\section{Cellular and subcellular distribution of immunoreactive enkephalinase}

The striosomal distribution of enkephalinase immunoreactivity was readily apparent in 1- $\mu \mathrm{m}$-thick sections from Epon-embedded material. In addition, the high resolution afforded by this technique made it possible to determine that, both within and outside striosomes, the radioactivity was preferentially distributed over the neuropil and hence was mainly associated with neuronal and/or glial processes.

Probability circle analysis of silver grain distribution in the electron microscopic radioautographs indicated that more than $90 \%$ of the grains were shared (i.e., overlaid apposed cellular elements). This proportion corresponds to that expected, on the basis of line source analyses, to arise from a population of radioactive sources selectively associated with either 1 or both of the apposed plasma membranes (Dana et al., 1989). In contrast, less than $75 \%$ of uniformly distributed hypothetical grains were associated with mcmbrane intcrfaces, confirming that the observed membrane enrichment did not result from an overrepresentation of membrane compartments in our material.

Examination of PAP-reacted material confirmed the exclusive association of enkephalinase immunoreactivity with cellular plasma membranes. Such a localization is consistent with the results of subcellular fractionation studies in the rat, which have shown enkephalinase activity to be enriched in P2 membrane fractions (De la Baume et al., 1981), as well as results of immunocytochemical studies in the pig, which have demonstrated a selective association of the enzyme with plasma membranes in the globus pallidus (Barnes et al., 1988b). Both acetylcholinesterase- and angiotensin-converting enzymes were likewise found to be predominantly associated with plasmalemma in the mammalian CNS (Hendersen and Greenfield, 1984; Pickel et al., 1986). However, these 2 enzymes were also shown to be present in intracellular membrane systems (including the rough endoplasmic reticulum, Golgi apparatus, and large membrane-bound vesicles), which we did not find to be the case for enkephalinase. Interestingly, when visualized in the rat neostriatum by means of an enzymatic histochemical method, enkephalinase appeared to be mainly intraneuronal (Back and Gorenstein, 1989). The failure of our antibody to detect intracellular enzymatic pools may reflect low intracellular stores of the enzyme or conformational changes such that the antiserum recognizes it only after more complete assembly within the plasma membrane.

Both radioautographic and PAP immunodetection methods revealed a predominant association of immunoreactive enkephalinase with neuronal elements. However, both the relative enrichment of neural-glial interfaces in radioautographs and the presence of peroxidase deposits along the plasma membrane of certain oligodendrocytes and astrocytic leaflets in PAP/DABreacted material indicated that part of the immunoreactive enzyme was also associated with glial cells. These results, though at variance with immunocytochemical observations in the pig globus pallidus (Barnes et al., 1988b), are in keeping with earlier data showing an association of the enzyme with astrocytes from the chick or murine brain in culture (Horsthemke et al., 1983; Lentzen and Palenker, 1983; Lentzen et al., 1983) or with Schwann cells in pig peripheral nerves (Matsas et al., 1986). In fact, several ectoenzymes, including angiotensin-converting enzyme, have been shown to be present on glial as well as on neuronal elements in the mammalian CNS (Koshiya et al., 1984; Pickel et al., 1986). Whether glia-associated enkephalinase subserves the same physiological role as the neural enzyme remains to be establishcd.

Quantitative analysis of electron microscopic radioautographs revealed that the bulk of the immunoreactive enkephalinase was associated with neuronal interfaces involving dendrites. Peroxidase immunocytochemistry confirmed the presence of enkephalinase immunostaining along the plasma membrane of both dendritic shafts and dendritic spines. This finding is consistent with the marked decrease in enzymatic activity (Malfroy et al., 1979), enkephalinase immunoreactivity (Pollard et al., 1987b), and binding of tritiated enkephalinase inhibitors (Waksman et al., 1987) reported in the rat neostriatum following local injection of kainic acid. It also conforms to the presence of a large number of neostriatal perikarya reactive for enkephalinase in material processed by histochemistry (Back and Gorenstein, 1989) or found to express enkephalinase mRNA by in situ hybridization (Pollard et al., 1989b; Wilcox et al., 1989). The fact that immunorcactive cnkephalinasc was found in the present study to be associated with both spiny dendrites and medium-sized neuronal perikarya suggests that at least some of these enkephalinase-containing neurons correspond to medium spiny neurons (i.e., to striatofugal neurons; for a review, see Graybiel and Ragsdale, 1983). Consistent with this interpretation are the reports of intense labeling of striatofugal pathways in sections of pig (Barnes et al., 1988a) and rat (Pollard et al., 1987b, 1989a) brain immunoreacted for enkephalinase, as well as the frequency with which interfaces between myelinated axons and their myelin sheaths were found to be labeled in our immunoradioautographic material. Also consistent with this view is the substantial drop in enkephalinase activity and binding of radiolabeled inhibitors recorded in the globus pallidus and substantia nigra following injection of kainic acid (Waksman et al., 1986b; Pollard et al., 1987b) or colchicine (Waksman et al., 1987) into the caudate putamen.

Part of the immunoreactive enkephalinase detected in the neostriatum was observed in association with axon terminals and unmyelinated axons. Some of these axons likely represent local arborizations of striatal projection neurons. Others could theoretically correspond to projections from the cerebral cortex, because the latter has been shown to contain both perikarya histochemically reactive for enkephalinase (Back and Gorenstein, 1989) and neurons hybridizing enkephalinase mRNA (Wilcox et al., 1989). A cortical origin appears unlikely, however, given that cortical ablation was found to not modify the binding of the enkephalinase inhibitor ${ }^{3} \mathrm{H}-\mathrm{HACBO}-\mathrm{gly}$ in the rat neostriatum (Waksman et al., 1987). In contrast, lesions of the dopaminergic neostriatal pathway were found to induce a small but significant decrease of enkephalinase activity in rat striatal membranes, suggesting that a proportion of the enkephalinase-immunoreactive axons might be originating from the substantia nigra (Malfroy et al., 1979). However, substantia nigra neurons are unlikely to contribute substantially to striatal enzymatic pools, given that no enkephalinase mRNA-hybridizing cells were found to be present in this area (Pollard et al., 1989b; Wilcox et al., 1989) and that no modification in the binding of enkephalinase inhibitors was detected in sections from rat neostriatum following selective destruction of the nigrostriatal pathway by 6-hydroxydopamine (Waksman et al., 1987). 
Quantitative analysis of electron microscopic radioautographs revealed that immunoreactive enkephalinase was not concentrated at the level of specific membrane interfaces but showed an overall distributional pattern comparable to that of shared hypothetical grains, implying a fairly diffuse investment of labeled plasma membranes. A similarly diffuse localization of the enzyme was apparent in peroxidase-reacted material, though it was also evident from the latter that the labeling was not uniformly intense throughout the surface of immunoreactive plasmalemmas. The fact that high labeling densities were often visible along those parts of the membrane directly apposing other labeled elements suggests that there could have been in vitro diffusion of the reaction product from one of the membranes to the next (Novikoff et al., 1972; Courtroy et al., 1983). This interpretation remains unlikely, however, given the virtual absence of immunoprecipitate in the extracellular space.

At high magnification of PAP-immunoreacted material, a microheterogeneity was apparent in the deposition of the reaction product along the labeled membranes. Such heterogeneity could have been due to technical factors, such as steric hindrance, or might reflect the presence of specific sites of insertion of the enzyme along the membrane. Other ectoenzymes with clear transmembrane and cytoplasmic domains, such as acetylcholinesterase, alkaline phosphatase, and aminopeptidases, have indeed been postulated to be tightly anchored to the cell surface through interactions with submembranous actin filaments (Kenny et al., 1987).

In immunoperoxidase-reacted material, the natural electron density of postsynaptic membrane specializations made it difficult to assess whether synapses were enriched in immunoreactive enkephalinase. However, quantification of immunoradioautographs clearly indicated that synaptic specializations were labclcd with a frequency lower than that predicted on the basis of a uniform membrane distribution and, hence, that synapses, if anything, were less immunoreactive than nonsynaptic zones of the membrane. It is important to recall in this context that both mu (Hamel and Beaudet, 1987) and delta (Pasquini et al., 1988) opioid receptors radioautographically labeled in the rat neostriatum showed a similar lack of preferential association with synaptic junctions. This similarity, together with the concentration of enkephalinase found here at the level of opioidreceptor-rich striosomes, lends support to the concept that this ectoenzyme is involved in the inactivation of endogenous opioids at their site of action. This is not to say that the same enzyme may not also play a role in the inactivation of other modulatory peptides, such as tachykinins, neurotensin, or angiotensin II, which are known to be present in high concentrations in the mammalian neostriatum (for a review, see Graybiel and Ragsdale, 1983) and have been shown to be appropriatc substrates for enkephalinase in vitro, though such a role remains to be established.

The mismatch between the distribution of enkephalins and that of opioid receptors in the rat neostriatum (Lewis et al., 1985), together with the predominantly nonsynaptic localization of mu opioid receptors in the rat neostriatum, has led to the hypothesis that opioid peptides might diffuse in the extracellular space to act upon relatively distant receptive targets (Cuello, 1983; Hamel and Beaudet, 1987; Herkenham, 1987). The present results indicate that if enkephalinase is indeed strategically located to inactivate opioid peptides at their target sites, its widespread distribution on the surface of striatal cells may also hamper their diffusion across large distances and hence dampen this postulated broadcasting effect. Further studies are obviously needed to assess whether this also holds true in other brain areas less richly endowed in enkephalinase than the neostriatum.

\section{References}

Alstein M, Vogel Z (1980) On the inactivation of enkephalin by enkephalinase. In: Neurotransmitters and their receptors (Littanes VZ, ed), pp 497-507. New York: Wiley.

Back SA, Gorenstein C (1989) Histochemical visualization of neutral endopeptidase-24-11 (enkephalinase) activity in rat brain: cellular localization and codistribution with enkephalins in the globus pallidus. J Neurosci 9:4439-4455.

Barnes K, Matsas R, Hooper NM, Turner AJ, Kenny AJ (1988a) Endopeptidase-24.11 is striosomally ordered in pig brain and, in contrast to aminopeptidase $\mathrm{N}$ and peptidyl dipeptidase $\mathrm{A}$ ('Angiotensin converting enzyme'), is a marker for a set of striatal cfferent fibres. Neuroscience 27:799-817.

Barnes K, Turner AJ, Kenny AJ (1988b) Electron microscopic immunucytochemistry of pig brain shows that endopeptidase-24.11 is localized in neuronal membranes. Neurosci Lett 94:64-69.

Beaudet A, Descarries L (1987) Ultrastructural identification of serotonin neurons. In: Monoaminergic neurons: light microscopy and ultrastructure (Steinbusch HWM, ed), pp 265-313. Chichester: Wiley.

Blackett NM, Parry DM (1977) A simplified method of "hypothetical grain" analysis of electron microscope autoradiographs. J Histochem Cytochem 25:206-214.

Checler F, Vincent JP, Kitabgi P (1983) Degradation of neurotensin by rat brain synaptic membranes: involvement of a thermolysin-like metalloendopeptidase (enkephalinase), angiotensin-converting enzyme, and other unidentificd peptidases. J Neurochem 41:375-384.

Courtroy PJ, Hunt Picton D, Farquhar MG (1983) Resolution and limitations of the immunoperoxidase procedure in the localization of extracellular matrix antigens. J Histochem Cytochem 31:945-951.

Cuello AC (1983) Nonclassical neuronal communication. Fed Proc Fed Am Soc Exp Biol 42:2912-2922.

Dana C, Vial M, Leonard K, Beauregard A, Kitabgi P, Vincent JP, Rostene W, Beaudet A (1989) Electron microscopic localization of neurotensin binding sites in the midbrain tegmentum of the rat. I. Ventral tegmental area and interfascicular nucleus. J Neurosci 9:22472257.

De la Baume S, Patey G, Schwartz JC (1981) Subcellular distribution of enkephalin-dipeptidyl carboxypeptidase (enkephalinase) in rat brain. Neuroscience 6:315-321.

Dubuc I, Nouel D, Costentin J, Kitabgi P (1989) L'inhibition de l'enképhalinase accroit la récupération de la neurotensine liberée par dépolarisation de coupes d'hypothalamus de souris. Annales d'Endocrinologie t50:26N.

Gafford JT, Skidgel RA, Erdös EG, Hersh LB (1983) Human kidney "enkephalinase", a neutral metalloendopeptidase that cleaves active peptides. Biochem 22:3265-3271.

Graybiel AM, Ragsdale CW (1983) Biochemical anatomy of the striatum. In: Chemical neuroanatomy (Emson PC, ed), pp 427-504. New York: Raven.

Gros C, Giros B, Llorens-Cortes C, Malfroy B, Pollard H, Pachot I, Schwartz JC, Mazie JC (1985) "Enkephalinase" and "amino peptidase M", as enkephalin-inactivating peptidases and their inhibition. Tran Biochem Soc 13:1185-1188.

Gros C, Souque A, Schwartz JC, Duchicr J, Cournot A, Baumer P, Leconte JM (1989) Protection of atrial natriuretic factor against degradation: diuretic and natriuretic responses after in vivo inhibition of enkephalinase (E.C.3.4.24.11) by acetorphan. Proc Natl Acad Sci USA 86:7580-7584.

Hamel E, Beaudet A (1987) Opioid receptors in rat neostriatum: radioautographic distribution at the electron microscopic level. Brain Res 401:239-257.

Henderson Z, Greenfield SA (1984) Ultrastructural localization of acetylcholinesterase in substantia nigra: a comparison between rat and guinea pig. J Comp Neurol 230:278-286.

Herkenham M (1987) Mismatches between neurotransmitter and receptor localization in brain: observations and implications. Neuroscience 23:1-38.

Hersh LB (1982) Degradation of enkephalins: the search for an enkephalinase. Mol Cell Biochem 47:35-43.

Horsthemke B, Hamprecht B, Bauer K (1983) Heterogeneous distri- 
bution of enkephalin-degrading peptidases between neuronal and glial cells. Biochem Biophys Res Commun 115:423-429.

Kenny AJ, Stephenson SL, Turner AJ (1987) Cell surface peptidases. In: Mammalian ectoenzymes (Kenny AJ, Turner AJ, eds), pp 169210. Amsterdam: Elsevier.

Koshiya K, Kato T, Tanaka R, Kato T (1984) Brain peptidases: their possible neuronal and glial localization. Brain Res 324:261-270.

Lentzen H, Palenker J (1983) Localization of the thiorphan-sensitive endopeptidase, termed enkephalinase A, on glial cells. FEBS Lett 153 : 93-97.

Lentzen H, Monden I, Linke J, Palenker J (1983) No evidence for enkephalinase A on neuronal cells. Life Sci 33:105-108.

Lewis ME, Khachaturian H, Watson SJ (1985) Combined autoradiographic-immunocytochemical analysis of opioid receptors and opioid peptide neuronal systems in brain. Peptides 6:37-47.

Llorens-Cortes C, Malfroy B, Schwartz JC, Gacel G, Roques BP, Roy J, Morgat JL, Javoy-Agid F, Agid Y (1982) Enkephalin dipeptidyl carboxypeptidase (enkephalinase) activity: selective radioassay properties and regional distribution in human brain. $\mathbf{J}$ Neurochem 39 : 1081-1089.

Lynch DR, Snyder SH (1986) Neuropeptides: multiple molecular forms, metabolic pathways and receptors. Ann Rev Biochem 55:773-799.

Malfroy B, Swerts JP, Guyon A, Roques BP, Schwartz JC (1978) High affinity enkephalin-degrading peptidase in brain is increased after morphine. Nature 276:523-526.

Malfroy B, Swerts JP, Llorens C, Schwartz JC (1979) Regional distribution of a high-affinity enkephalin-degrading peptidase ('Enkephalinase') and effects of lesions suggest localization in the vicinity of opiate receptors in brain. Neurosci Lett 11:329-334.

Marcel D, Pollard H, Vcrroust P, Schwartz JC, Bcaudet A (1989) Ultrastructural localization of enkephalinase (E.C.3.4.24.11) in rat neostriatum. Soc Neurosci Abst 15:739.

Matsas R, Kenny AJ, Turner AJ (1984) The metabolism of neuropeptides, the hydrolysis of peptides, including enkephalins, tachykinins and their analogues, by endopeptidase-24.11. Biochem J 223: $433-440$.

Matsas R, Kenny AJ, Turner AJ (1986) An immunohistochemical study of endopeptidase-24.11 ("enkephalinase") in the pig nervous system. Neuroscience 18:991-1012.

McConahey PJ, Dixon FJ (1966) A method of trace iodination of proteins for immunologic studies. Int Arch Allergy Appl Immunol 29:185-191.

McKelvy JF (1983) Enzymatic degradation of brain peptides. In: Brain pcptides (Krieger DT, Brownstein MJ, Martin JB, eds), pp 117-135. New York: Wiley.

McKelvy JF, Blumberg S (1986) Inactivation and metabolism of neuropeptides. Ann Rev Neurosci 9:415-434.

Novikoff AB, Novikoff PM, Quintana N, Davis C (1972) Diffusion artifacts in 3,3'-diaminobenzidine cytochemistry. J Histochem $\mathrm{Cy}$ tochem 20:745-749.

Pasquini F, Beaudet A, Bochet P, Rossier J, Roques BP (1988) Electron microscopic localization of delta opioid receptors in rat brain. Soc Neurosci Abst 14:353.

Pickel VM, Chan J, Ganten D (1986) Dual peroxidase and colloidal gold-labeling study of angiotensin converting enzyme and angiotensin-like immunoreactivity in the rat subfornical organ. J Neurosci 6: 2457-2469.

Pollard II, De la Baume S, Bouthenet ML, Schwartz JC, Ronco P, Verroust $\mathbf{P}$ (1987a) Characterization of two probes for the localization of enkephalinase in rat brain: ${ }^{3} \mathrm{H}$-thiorphan and a ${ }^{125} \mathrm{I}$-labeled monoclonal antibody. Eur J Pharmacol 133:155-164.

Pollard H, Llorens-Cortes C, Couraud JY, Ronco P, Verroust P, Schwartz JC (1987b) Enkephalinase (EC 3.4.24.11) is highly localized to a striatonigral pathway in rat brain. Neurosci Lett 77:267-271.

Pollard H, Bouthenet ML, Moreau J, Souil E, Verroust P, Ronco P, Schwartz JC (1989a) Detailed immunoautoradiographic mapping of enkephalinase (EC 3.4.24.11) in rat central nervous system: comparison with enkephalins and substance $P$. Neuroscience 30:339-376.

Pollard H, Wilcox JN, Malfroy B, Ronco P, Verroust P, Schwartz JC (1989b) Localization of enkephalinase in rat brain: comparison of radioimmunohistochemical and mRNA hybridization data. In: Progress in opioid research (Cros J, Meunier JC, Ilamon N, eds), pp 317-320. Oxford, Eng: Pergamon.
Relton JM, Gee NS, Matsas R, Turner AJ, Kenny AJ (1983) Purification of endopcptidase-24.11 ("cnkephalinase") from pig brain by immuno absorbent chromatography. Biochem J 215:519-523.

Ronco P, Geniteau M, Poujeol P, Melcion C, Verroust P, Vandewalle A (1986) Characterization of monoclonal antibodies to rabbit renal cortical cells. Am J Physiol 250:C506-C516.

Ronco P, Pollard H, Galceran M, Delauche M, Schwartz JC, Verroust P (1988) Distribution of enkephalinase (membrane metalloendopeptidase, EC 3.4.24.11) in rat organs: detection using a monoclonal antibody. Lab Invest 58:210-217.

Salpeter MM, McHenry FA, Salpeter EE (1978) Resolution in electron microscopic autoradiography. IV. Application to analysis of autoradiographs. J Cell Biol 76:127-145.

Schwartz JC (1983) Metabolism of enkephalins and the concept of neuropeptidase. Trends Neurosci 6:45-48.

Schwartz JC (1988) Enkephalinasc inhibitors as drugs. In: Design of enzyme inhibitors as drugs (Sandler M, Smith J, eds), pp 206-226. Oxford: Oxford UP

Schwartz JC, Malfroy B, De la Baume S (1981) Biological inactivation of enkephalins and the role of enkephalin-dipeptidycarboxypeptidase ("enkephalinase") as neuropeptidase. Life Sci 29:1715-1740.

Schwartz JC, Costentin J, Leconte JN (1985) Pharmacology of enkephalinase inhibitors. Trends Pharmacol Sci 6:472-476.

Schwartz JC, De la Baume S, Bouthenet ML, Giros B, Gros C, Llorens C, Pollard H, Sales N, Solhonne B, Costentin J, Leconte JN (1986a) Neuropeptidase responsable de l'inactivation des enkephalines et pharmacologie de leurs inhibiteurs. J Pharmacol 17:104-122.

Schwartz JC, Gros C, Giros B, Llorens C, Malfroy B, Rose C, Zozel K, Pollard H, Pachot I, Nazie JC (1986b) Ectopeptidase responsible for the inactivation of enkephalins. In: Ccllular biology of ectocnzymes (Kreutzberg GW, Reddington M, Zimmerman H, eds), pp 272284. Berlin: Springer-Verlag.

Sonnenberg JL, Sakane Y, Jeng AY, Koehn JA, Ansell JA, Wennogle LP, Ghai RD (1988) Identification of protease 3.4.24.11 as the major atrial natriuretic factor degrading enzyme in the rat kidney. Peptides 9:173-180.

Stephenson SL, Kenny AJ (1987a) The metabolism of neuropeptides: hydrolysis of the angiotensins, bradykinin, substance $P$ and oxytocin by pig kidney microvillar membranes. Biochem J 241:237-247.

Stephenson SL, Kenny AJ (1987b) The hydrolysis of $\alpha$-human atrial natriuretic peptide by pig kidney microvillar membranes is initiated by endopeptidase-24.11. Biochem J 243:183-187.

Sternberger LA (1979) Immunocytochemistry. New York: Wiley.

Swerts JP, Perdrisot R, Patey G, De la Baume S, Schwartz JC (1979) Is "enkephalinase" identical with "angiotensin-converting enzyme"? Eur J Pharmacol 53:209-210.

Waksman G, Hamel E, Bouboutou R, Besselièvre R, Fournie-Zaluski MC, Roques BP (1984) Distribution régionale de l'enképhalinase dans le cerveau du rat par autoradiographie. CR Acad Sci (Paris) 299: 613-615.

Waksman G, Hamel E, Fournie-Zaluski MC, Roques BP (1986a) Autoradiographic comparison of the distribution of the neutral endopeptidase "enkephalinase" and of $\mu$ and $\delta$ opioid receptors in rat brain. Proc Natl Acad Sci USA 83:1523-1527.

Waksman G, Hamel E, Delay-Goyet P, Roques BP (1986b) Neuronal localization of the neutral endopeptides "enkephalinase" in rat brain revealed by lesions and autoradiography. EMBO J 5:3163-3166.

Waksman G, I Iamel E, Delay-Goyet P, Roques BP (1987) Neutral endopeptidase-24.11, $\mu$ and $\delta$ opioid receptors after selective brain lesions: an autoradiographic study. Brain Res 436:205-216.

Wilcox JN, Pollard H, Moreau J, Schwartz JC, Malfroy B (1989) Localization of enkephalinase mRNA in rat brain by in situ hybridization: comparison with immunohistochemical localization of the protein. Neuropeptides 14:77-83.

Williams MA (1969) The assessment of electron microscopic autoradiography. In: Advances in optical and electron microscopy (Baker R, Cosslett VE, eds), pp 219-272. New York: Academic.

Zuzel KA, Rose C, Schwartz JC (1985) Assessment of the role of "enkephalinase" in cholecystokinin inactivation. Neurosci 15:149_ 158. 